\title{
Effect of sandalwood oil on inhibition of reactive oxygen species generation and lipopolysaccharide- induced inflammation through down-regulation of the nuclear factor- $\kappa B$ signaling pathways
}

\author{
Young Min Lee ${ }^{\mathrm{a}}$, In Sook Kim ${ }^{\mathrm{a}}$, Beong Ou Lim ${ }^{\mathrm{a}, \mathrm{b}, *}$ \\ a Department of Medicinal Bioscience, Division of Integrated Bioscience, College of Biomedical \& \\ Health Science, Konkuk University, Chungju 27478 Korea \\ b Research Institute of Inflammatory Diseases, Kunkuk University, Chungju 27478 Korea
}

*Corresponding author, e-mail: beongou@kku.ac.kr

Received 6 Dec 2019

Accepted 30 Nov 2020

\begin{abstract}
We investigated the antioxidative and anti-inflammatory effects of sandalwood oil and attempted to elucidate its underlying mechanism of action. The antioxidant activities of sandalwood oil were assessed using various methods: 1.1-diphenyl-2-picrylhydrazyl (DPPH) and 2,2'-azino-bis(3-ethylbenzothiazoline-6-sulphonic acid (ABTS ${ }^{+}$) radical scavenging assays, as well as DNA protection ability and reactive oxygen species (ROS) generation. The cell viability of sandalwood oil in RAW 264.7 cells (murine macrophage) was investigated by tetrazolium salt (MTT) assay. The nuclear factor kappa B (NF- $\kappa$ B) activation was analyzed by western blot analysis in LPS-induced RAW 264.7 cells. NF- $\kappa B$ nuclear translocation was evaluated by immunofluorescence staining. Furthermore, we examined ROS

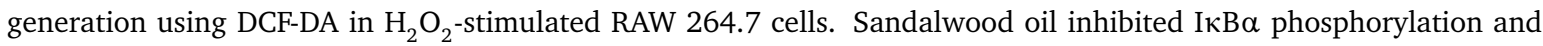
$\mathrm{NF}-\kappa \mathrm{B}$ activation and its translocation into the nucleus. Sandalwood oil shows antioxidant activity in vitro, suggesting that it may inhibit the promotion of the NF- $\kappa \mathrm{B}-$ mediated inflammatory signaling pathway induced by ROS.
\end{abstract}

KEYWORDS: anti-inflammation, anti-oxidation, ROS, nuclear factor kappa B, sandalwood oil

\section{INTRODUCTION}

Inflammation is a protective response activated by biological reactions to harmful pathogens, damaged cells, and external stimuli of living tissues [1]. Inflammation inhibits early cell damage and promotes tissue regeneration; it moreover, facilitates the elimination of necrotic cells and scar tissue from the wound [2]. Macrophages are the primary cell involved in the inflammatory response and are activated by cytokines exposed to external stimuli or secreted by immune cells; hence, macrophages play an important role in biological defense by producing cytokines in the early stage of infection [3]. The mitogen-activated protein kinase (MAPK) signaling pathway and the nuclear factor kappa B (NF- $\kappa$ B) signaling pathway are well-known inflammatory pathways in macrophages. Lipopolysaccharide (LPS), a component of the bacterial wall and macrophage cell lineage, interacts with toll-like receptor (TLR)-4 of macrophages and stimulates the MAPK and NF- $\kappa B$ signaling pathways [4]. MAPK, one of the inflammatory signaling pathways, is activated by the three subtypes of extracellular signal-regulated kinases (ERKs), the c-Jun N-terminal kinases (JNKs), and the p38 MAPK. The three subtypes can induce physiological activities, such as inflammation, apoptosis, differentiation, and proliferation. The ERK, JNK, and p38 subtypes are activated by phosphorylation of MAPK kinase (MAPKK) and MAPKK kinase (MAPKKK), primarily via JNK and p38 groups in inflammation. At this time, reactive oxygen species (ROS) act on ASK-1, one of the MAPKKKs, to induce activation of JNK and p38 groups, thereby promoting inflammation [5]. NF- $\kappa \mathrm{B}$ is a transcription factor that plays an important role in regulating the synthesis of various cytokines during inflammation [6]. NF- $\kappa \mathrm{B}$ comprises P50 and P65 (RelA) and is normally inactivated by binding with Inhibitors of $\kappa \mathrm{B} \alpha(\mathrm{I} \kappa \mathrm{B} \alpha)$ [7]. In LPS- treated RAW 264.7 macrophages, the NF- $\kappa \mathrm{B}$ signaling pathway is activated by TLR-4 to phosphorylate $I \kappa B \alpha$ by activating I $\mathrm{B} \alpha$ kinase (IKK), which phosphorylates $\operatorname{I\kappa } B \alpha[8,9]$. When phosphorylated $I \kappa B \alpha$ is isolated from NF- $\kappa \mathrm{B}, \mathrm{NF}-\kappa \mathrm{B}$ functions as a transcription factor. Cytoplasmic NF- $\kappa \mathrm{B}$ migrates into the nucleus 
and plays an important role in the inflammatory response by binding specific DNA sequences in the promoter region of the target gene and inducing the expression of various pro-inflammatory genes, including those encoding cytokines [10].

Cyclooxygenase-2 (COX-2) is involved in the conversion of arachidonic acid into prostaglandin and promotes inflammation via prostaglandin E2 synthesis, thereby mediating inflammatory responses such as edema and fever [11]. The inflammatory response by this signaling process is a very essential and beneficial response; however, failure to control inflammation can lead to chronic inflammation and other secondary diseases.

ROS are oxygen free radicals produced by the chemical properties of oxygen and have very high reactivity; however, they are mainly produced in vivo by the electron transport system involved in ATP synthesis [12]. ROS are regulated in vivo by antioxidant enzymes, and ROS regulated at appropriate levels serve as second messengers during signal transduction and gene regulation in various cell types and cytokines, growth factors, and transcription factors [13]. However, when cellular ROS generation exceeds the antioxidant capacity, cells acquire a state of oxidative stress and undergo severe damages contributing to the pathogenesis of various diseases. ROS also play an important role in the inflammatory response via the inflammatory signal transduction pathway [14]. In NF- $\mathrm{BB}$-mediated inflammatory responses, ROS activate IKK, thereby increasing the DNA binding of NF- $\mathrm{KB}$ and promoting the COX-2 expression, etc [15]. Thus, ROS generation is closely associated with inflammation.

Santalum album L. (Santalaceae), commonly known as East Indian sandalwood, is a slowgrowing meniscus tree widely distributed in South Asia. Indian sandalwood trees have been used as scents and sculptures from ancient times for religious purposes and are used as perfumes, spices, and traditional medicines [16]. Sandalwood essential oils are usually obtained via steam distillation and are widely used in aromatherapy and as antidepressants, anti-inflammatory and antifungal agents, astringents, sedatives, insecticides, and fungicides [17]. The primary components are (Z)-asantalol, (Z)-a-exo-bergamotol, (Z)-b-santalol, and (Z)-epi-b-santalol [18]. Besides, sandalwood essential oils reportedly inhibited atopic skin inflammation and ROS generation in ICR mice [19]. However, the mechanism underlying the antiinflammatory effects of sandalwood oil is unclear. Therefore, in this research, we investigated the an- tioxidative and anti-inflammatory effects of sandalwood oil and attempted to elucidate its underlying mechanism of action.

\section{MATERIALS AND METHODS}

\section{Experimental material and reagent}

Sandalwood oil used in the experiment was supplied by Namcheon Co., Ltd. in Seoul, South Korea. Ascorbic acid (AA), Folin-Ciocalteu reagent (FC reagent), DPPH, ABTS, potassium persulfate, ferrous sulfate $\left(\mathrm{FeSO}_{4}\right)$, anhydrous sodium phosphate monobasic, ferrous chloride $\left(\mathrm{FeCl}_{2}\right)$, pyrogallol, and ammonium thiocyanate were purchased from Sigma Chemical Co. (St. Louis, Missouri, USA). Ferric chloride $\left(\mathrm{FeCl}_{3}\right)$ and sodium hydroxide $(\mathrm{NaOH})$ were obtained from Wako Pure Chemical Industries Ltd. (Tokyo, Japan). The pBR322 DNA and 6X DNA loading dyes were purchased from Fermentas Inc. (Glen Burnie, MD). The catalase assay kit was purchased from Cayman Chemical Company (Ann Arbor, MI, USA).

\section{Measurement of DPPH radical scavenging activity}

Ascorbic acid, which was used as a positive control, was prepared with water to concentrations of 0.03 , $0.1,0.3,1$, and $3 \%$. Samples of sandalwood oil were dissolved in DMSO to a final concentrations of $0.03,0.1,0.3,1$ and $3 \%$. DPPH radical scavenging activity of the sample was measured according to the previously reported method [20]. The sample and standard of $80 \mu \mathrm{l}$ were added to the 96-well plate and $80 \mu \mathrm{l}$ of DPHH was added to each well. The 96-well plate was wrapped with foil to prevent exposure to light and allowed to stand at room temperature for $30 \mathrm{~min}$. Absorbance was measured at $517 \mathrm{~nm}$, using an ELISA reader (16039400, Tecan, Männedorf, Switzerland).

DPPH radical scavenging activity was calculated as follows: DPPH radical scavenging activity (\%) $=[$ (Absorbance of the control - Absorbance of the sample)/Absorbance of the control] $\times 100$.

\section{Measurement of ABTS radical scavenging activity}

$7 \mathrm{mM} \mathrm{ABTS}$ and $2.45 \mathrm{mM}$ potassium persulfate, which were dissolved in water, were mixed in equal amounts and then allowed to stand in the dark for 12-16 $\mathrm{h}$ for ABTS radical generation. For each experiment, prepared ABTS solution was diluted with $0.01 \mathrm{M}$ phosphate buffer saline (PBS, pH 7.4) to adjust its absorbance to within $0.70 \pm 0.02$ at 
$734 \mathrm{~nm}$ wavelength [20]. Thereafter, $0.2 \mathrm{ml}$ of each concentration of the sample $(0.03,0.1,0.3,1$, and $3 \%)$ and the ascorbic acid $(0.03,0.1,0.3,1$, and $3 \%$ ) mixed with $0.8 \mathrm{ml}$ of ABTS solution. Lastly, the absorbance was measured at $734 \mathrm{~nm}$ following incubation at room temperature for $5 \mathrm{~min}$.

ABTS radical scavenging activity was calculated as follows; ABTS radical scavenging activity $(\%)=$ [(Absorbance of the control - Absorbance of the sample)/Absorbance of the control] $\times 100$.

\section{Reducing power assay}

Reducing power activity was determined according to $\mathrm{Hu}$ et al method [21] with slight modification. $500 \mu \mathrm{l}$ of sample and ascorbic acid (positive control) at various concentrations $(0.03,0.1,0.3,1$, and $3 \%$ ) were individually mixed with $500 \mu \mathrm{l}$ of $0.2 \mathrm{M}$ PBS (pH 6.6) and $500 \mu \mathrm{l}$ of potassium ferricyanide $(10 \mathrm{mg} / \mathrm{ml})$ and allowed to react in a water bath at $50{ }^{\circ} \mathrm{C}$ for $20 \mathrm{~min}$. Thereafter, $1 \mathrm{ml}$ of the mixture was transferred to a new e-tube and $500 \mu \mathrm{l}$ of $100 \mathrm{mg} / \mathrm{ml}$ TCA were added. After centrifugation for $10 \mathrm{~min}$ at $3000 \mathrm{rpm}, 500 \mu \mathrm{l}$ of the supernatant were transferred to a new e-tube and mixed with $500 \mu$ l of distilled water (DW) followed by the addition of $100 \mu \mathrm{l} \mathrm{of} \mathrm{FeCl}_{3}$ solution $(1 \mathrm{mg} / \mathrm{ml})$. The absorbance was measured at $700 \mathrm{~nm}$ with an ELISA reader (16039400, Tecan, MÃd'nnedorf, Switzerland).

\section{Measurement of DNA protection ability}

The prevention of oxidative DNA damages by $\mathrm{H}_{2} \mathrm{O}_{2}$ due to oxidative stress was performed as described by Tian \& Hua [22] with some minor modifications. Briefly, $1 \mu \mathrm{l}$ of plasmid pBR DNA $(0.5 \mu \mathrm{g} / \mathrm{ml})$ was treated with $3 \mu \mathrm{l}$ of $\mathrm{FeSO}_{4}(0.08 \mathrm{mM}), 3 \mu \mathrm{l}$ of distilled water, $4 \mu \mathrm{l}$ of $30 \% \mathrm{H}_{2} \mathrm{O}_{2}(\mathrm{v} / \mathrm{v})$, and $2 \mu \mathrm{l}$ of sandalwood oil at different concentrations (0.1, $0.3,1 \%)$. The total volume of reaction mixture was adjusted to $13 \mu \mathrm{l}$ and incubated for $1 \mathrm{~h}$ in a $37^{\circ} \mathrm{C}$ water bath (HB10D, IKA, Staufen, Germany). After incubation, $2 \mu \mathrm{l}$ of $6 \mathrm{X}$ DNA loading dye were added to the mixture, and the extent of DNA damages and the preventive effect of sandalwood oil were analyzed on $0.8 \%$ agarose gel electrophoresis at $100 \mathrm{~V}$ at room temperature for $30 \mathrm{~min}$. The DNA bands (supercoiled, open circular and linear) were stained with ethidium bromide (EtBr) and the gels scanned on a Gel documentation system (Nextep, Korea). The DNA band intensity was quantified using ChemiDoc (10016025, Bio-Rad, Hercules, CA, USA). Evaluations of antioxidant effects on DNA were based on the increase or loss in percentage of supercoiled monomers, compared with the control values.

\section{Cell culture}

RAW264.7 cells, a mouse macrophage cell line, were obtained from the Korean Cell Line Bank (Seoul, Korea) and cultured in Dulbecco's Modified Eagle Medium (DMEM), supplemented with 10\% heat-inactivated fetal bovine serum (FBS) (Gibco BRL, Gaithersburg, MD, USA), $100 \mathrm{U} / \mathrm{ml}$ penicillin, and $100 \mathrm{mg} / \mathrm{ml}$ streptomycin, in a humidified atmosphere of $5 \% \mathrm{CO}_{2}$ at $37^{\circ} \mathrm{C}$.

\section{Measurement of cell viability}

Cell viability was determined using the 3-(4,5dimethyl-2-thiazolyl)-2,5-diphenyl-2H-tetrazolium bromide (MTT) assay. RAW264.7 cells were seeded at a density of $5 \times 10^{4}$ cells/well in a 96-well plate with $100 \mu \mathrm{l}$ DMEM medium containing 10\% heat-inactivated FBS and cultured for $24 \mathrm{~h}$. Then, the cells were treated with different concentrations of sample $(0.1,0.3,1.0$, and $3 \mu \mathrm{g} / \mathrm{ml})$ and cultured again for $24 \mathrm{~h}$. After that, $50 \mu \mathrm{l}$ of MTT solution $(2 \mathrm{mg} / \mathrm{ml})$ were added into each well and incubated at $37^{\circ} \mathrm{C}$ for $2 \mathrm{~h}$. The medium was discarded, and the formazan blue formed in the cells was dissolved in $150 \mu$ l of dimethyl sulfoxide (DMSO). The optical density was measured at $540 \mathrm{~nm}$ wavelength using an ELISA reader (16039400, Tecan, Männedorf, Switzerland).

\section{Measurement of ROS generation}

Intracellular formation of ROS was measured using oxidation-sensitive dye DCFH-DA as the substrate. RAW264.7 cells were seeded at $5 \times 10^{4}$ cells/well in a 96-well plate with DMEM medium containing $10 \%$ heat-inactivated FBS and cultured for $24 \mathrm{~h}$. Then, the cells were treated with different concentrations of sample $(0.1,0.3,1.0$, and $3 \mu \mathrm{g} / \mathrm{ml})$ and cultured again for $24 \mathrm{~h}$. After washing 3 times with PBS, the cells were treated with $100 \mu \mathrm{l}$ of $10 \mu \mathrm{m} \mathrm{H}_{2}$ DCF-DA for $1 \mathrm{~h}$ and, then, $10 \mu \mathrm{l}$ of $500 \mu \mathrm{m} \mathrm{H}_{2} \mathrm{O}_{2}$ for $1 \mathrm{~h}$ to induce ROS generation. The formation of fluorescent dichlorofluorescein (DCF), due to oxidation of DCFH in the presence of various ROS, was measured at the excitation wavelength of $485 \mathrm{~nm}$ and the emission wavelength of $530 \mathrm{~nm}$ using fluorescence microplate readers (SoftMax Pro 5, Sunnyvale, CA, USA).

\section{Western blot analysis}

In the case of Western blot, the medium was removed after culturing RAW264.7 cells for $24 \mathrm{~h}$. 
Sandalwood oil was treated at different concentrations, and LPS $(1 \mu \mathrm{g} / \mathrm{ml})$ was simultaneously treated in all sample wells except for the control wells, followed by incubation for $24 \mathrm{~h}$. After washing with ice-cold PBS, the cells were scraped from the plate using $1 \mathrm{ml}$ PBS, which was discarded after centrifugation at $7500 \mathrm{rpm}$ for $5 \mathrm{~min}$. To extract cellular proteins (COX-2, І $\kappa \mathrm{B} \alpha$, phospho-IкB $\alpha$ ), the cells were homogenized in radioimmunoprecipitation assay (RIPA) lysis buffer, and the homogenates were centrifuged at $14000 \mathrm{rpm}$ for $20 \mathrm{~min}$. On the other hand, NE-PER kit (Thermo scientific Co, MA, USA) was used to compare the cytoplasmic and nuclear NF- $\kappa \mathrm{B}$ expression levels. The total protein content concentration was measured using a Bio-Rad Protein Assay reagent (Bio-Rad, CA, USA). Proteins (20 $\mu \mathrm{g}$ per lane) were separated using SDSpolyacrylamide gel electrophoresis and transferred from the gel to nitrocellulose membranes. The membranes were blocked in 5\% BSA and incubated overnight with each primary antibodies, including COX-2, ІкB $\alpha$, phospho-IкB $\alpha$, NF- $\kappa B$, and anti- $\beta$ actin antibodies, at $4^{\circ} \mathrm{C}$. The membranes were then incubated with the corresponding secondary antibodies, and the targeted proteins in the membranes were visualized by using enhanced chemiluminescence (ECL) reagents. The relative intensities of the bands were visualized and analyzed using the BIORAD ChemiDoc XRS+ (BIO-RAD, Philadelphia, PA, USA) imaging system with Image Lab software.

\section{Immunofluorescence staining}

RAW264.7 cells were seeded in an 8-well chamber at $1 \times 10^{4}$ cells/well for immunostaining. After overnight incubation, all the sample groups, were treated with $1 \mu \mathrm{g} / \mathrm{ml}$ of LPS and 1\% sandalwood oil. On the following day, cells were fixed with $4 \%$ formalin for $20 \mathrm{~min}$ at $4^{\circ} \mathrm{C}$. After washing with PBS, cells were permeabilized with PBS containing $0.1 \%$ Triton X-100 for $10 \mathrm{~min}$ at room temperature. After blocking with $1 \% \mathrm{BSA}$ at $37^{\circ} \mathrm{C}$ for $1 \mathrm{~h}$, FITClabeled anti-NF- $\kappa \mathrm{B}$ primary antibody was added and the cells were incubated overnight at $4{ }^{\circ} \mathrm{C}$. After washing with PBS containing $0.01 \%$ Triton X-100, the cells were treated with FITC/PE-labeled goat anti-rabbit IgG for $2 \mathrm{~h}$ at room temperature. DAPI staining was performed at room temperature for 15 min. Thereafter, the cells were washed with PBS, mounted, and observed using a fluorescence microscope (Olympus BX-40).

\section{Statistical analysis}

All results were expressed as mean \pm standard deviation from triplicate experiments. Statistical analysis was performed using GraphPad Prism 5.0 (GraphPad, La Jolla, CA, USA), and Duncan test was performed with one-way analysis of variance. The results were analyzed using Duncan's multiple-range test, and differences with $p<0.05$ were considered significant. A value of $p<0.05$ was considered to represent a statistically significant difference.

\section{RESULTS \\ Determination of antioxidant activity}

Antioxidant activities of sandalwood oil in vitro are shown in Fig. 1a. The sandalwood oil showed DPPH radical scavenging activities of $1.9 \%, 3.0 \%, 9.3 \%$, $12 \%$, and $26 \%$ at concentrations of $0.03,0.1,0.3$, 1 , and $3 \%$, respectively. Scavenging activities of DPPH increased significantly with increasing concentrations; however, they were lower than those of ascorbic acid.

The ABTS radical scavenging results are shown in Fig. 1b. As the concentrations of sandalwood oil increased from 0.03 to $0.1,0.3,1$, and $3 \%$, ABTS radical scavenging activities were increased from 8.2 to $14.2,17.8,30.8$ and $48.0 \%$, respectively. However, ABTS scavenging activities of sandalwood oil were lower than those of ascorbic acid. Results for the measurement of reducing power are shown in Fig. 1c. As the concentrations of sandalwood oil increased, the reducing power tended to increase; however, the reducing power was lower than that of standard ascorbic acid. Fig. 1d shows the protective effects of sandalwood oil against ROSmediated damaged (Dam) DNA. The supercoiled band of the damage group was reduced by hydroxyl radicals produced by the Fenton reaction with $\mathrm{FeSO}_{4}$ and $\mathrm{H}_{2} \mathrm{O}_{2}$. In the sandalwood oil treatment groups, the band intensity of the supercoiled form increased with increases in concentration and protected against ROS-mediated DNA damages.

\section{Effects of sandalwood oil on ROS generation in $\mathrm{H}_{2} \mathrm{O}_{2}$-induced RAW264.7 cells}

The cytotoxicity of sandalwood oil to the cell viability of $\mathrm{H}_{2} \mathrm{O}_{2}$-induced RAW264.7 cells is shown in Fig. 2a. The cell viability was $92.3 \%$ in the negative control group (NC) treated with $\mathrm{H}_{2} \mathrm{O}_{2}$ alone, which was significantly lower than that of the control group. When $\mathrm{H}_{2} \mathrm{O}_{2}$ and sandalwood oil were presented together, cell viabilities were 91.8$92.8 \%$ suggesting that there is no cytotoxicity by 

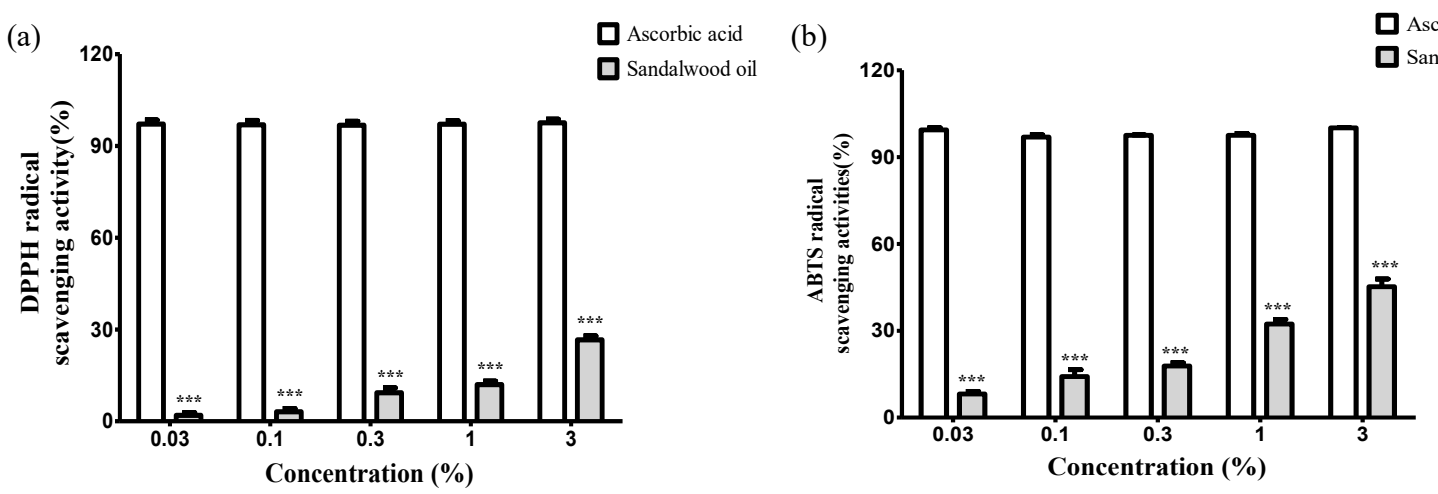

(c)

(d)

- BHT

- Ascorbic acid

- Sandalwood oil
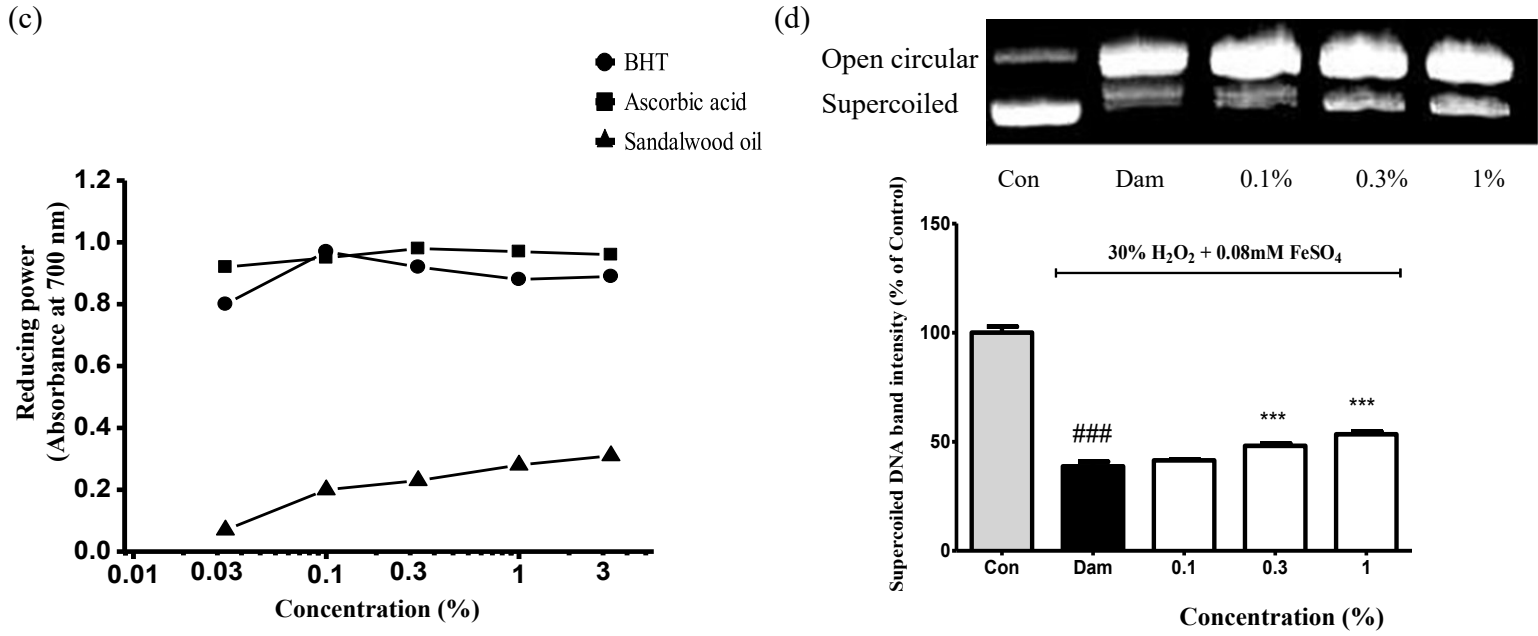

Fig. 1 Antioxidant activities in various concentrations of Sandalwood oil. (a) DPPH radical scavenging; (b) ABTS radical scavenging; (c) reducing power; and (d) DNA protection. Values are means $\pm \mathrm{SD}(n=3) ; * p<0.05, * * p<0.01$, and $* * * p<0.001$ were considered significant for positive control (butylated hydroxytoluene (BHT), ascorbic acid) vs. sample. Con $=$ control; Dam $=$ ROS-mediated damaged DNA.

(a)

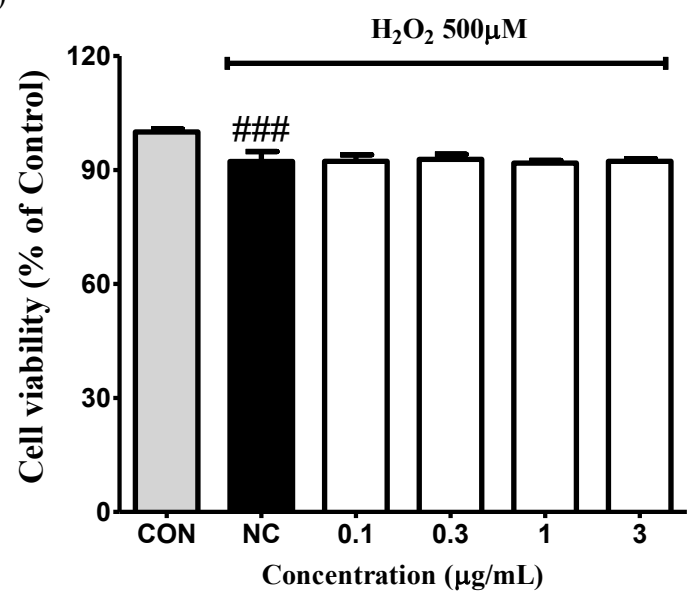

(b)

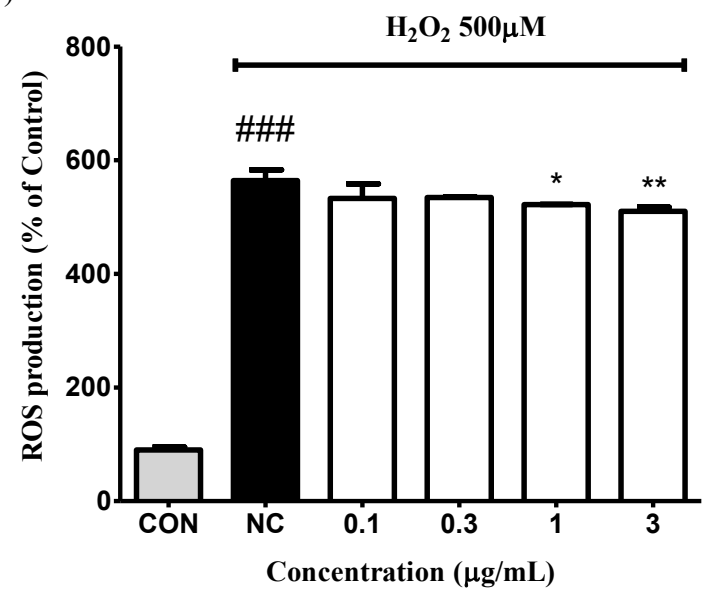

Fig. 2 (a) Cell viability and (b) ROS in various concentrations of sandalwood oil in RAW 264.7 cells. RAW 264.7 cells were treated with $\mathrm{H}_{2} \mathrm{O}_{2}(500 \mu \mathrm{m})$. ${ }^{\# \# \# ~} p<0.001$ were considered significant for control (not treated) vs. negative control (NC) where cells were treated by $\mathrm{H}_{2} \mathrm{O}_{2}$ without sample. ${ }^{*} p<0.05$ and ${ }^{* *} p<0.01$ were considered significant for negative control vs. sample. 
sandalwood oil treatment. Therefore, we further evaluated the inhibitory effect of sandalwood oil on ROS production in $\mathrm{H}_{2} \mathrm{O}_{2}$-induced RAW264.7 cells. To determine whether sandalwood oil reduced $\mathrm{H}_{2} \mathrm{O}_{2}$-induced ROS generation in RAW264.7 cells, the RAW cells were treated with sandalwood oil for $24 \mathrm{~h}$ and then incubated with $100 \mu \mathrm{l}$ of $10 \mu \mathrm{m}$ $\mathrm{H}_{2}$ DCF-DA for $1 \mathrm{~h}$, followed by incubation with $10 \mu \mathrm{l}$ of $500 \mu \mathrm{m}$ of $\mathrm{H}_{2} \mathrm{O}_{2}$ for $1 \mathrm{~h}$. The effect of sandalwood oil on the inhibition of $\mathrm{H}_{2} \mathrm{O}_{2}$-induced ROS generation in RAW264.7 cells is shown in Fig. 2b. $\mathrm{H}_{2} \mathrm{O}_{2}$-induced ROS generations in RAW264.7 cells were significantly increased in the $\mathrm{H}_{2} \mathrm{O}_{2}(500 \mu \mathrm{m})$ treatment groups compared with $\mathrm{H}_{2} \mathrm{O}_{2}$-untreated normal control group $(p<0.001)$. However, the treatment with sandalwood oil at the concentrations of 1.0 and $3.0 \mu \mathrm{g} / \mathrm{ml}$ significantly inhibited the $\mathrm{H}_{2} \mathrm{O}_{2}$-induced ROS generation in RAW264.7 cells indicating that sandalwood oil attenuates intracellular ROS generation.

\section{Effects of sandalwood oil on NF- $\kappa B$ activation and phosphorylation of IKK in LPS-induced RAW264.7 cells}

The activation of NF- $\mathrm{B}$, which is an important transcription factor in the inflammatory response, mediates the expression of several response genes involving in the inflammatory response, including iNOS and COX-2 [23]. That is, COX-2 and iNOS are inducible enzymes regulated by NF- $\kappa \mathrm{B}$ [24]. The transcription factor NF- $\kappa \mathrm{B}$ is present in the cytoplasm in the normal state. When stimulation, such as inflammatory cytokine occurs, the serine residue

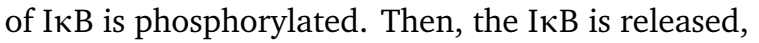
and the activated NF- $\kappa \mathrm{B}$ is transferred to the nucleus and involved in the expressions of various cytokines by binding to the genes and inducing transcriptions. Therefore, we measured the protein expressions of

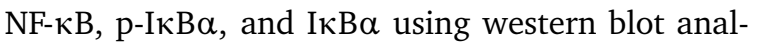
ysis to investigate whether increased COX-2 is due to NF- $\kappa \mathrm{B}$ activation and transcription in the nucleus (Fig. 3).

Fig. 3a shows the expression levels of $\mathrm{I} \kappa \mathrm{B} \alpha$ and phospho-IкB $\alpha$. In the NC group treated with LPS, IкB $\alpha$ was downregulated and phospho-IкB $\alpha$ was upregulated. Sandalwood oil treatment upregulated IкB $\alpha$ and downregulated phospho-ІкB $\alpha$, which inhibited the activation of NF- $\kappa \mathrm{B}$ via $\mathrm{I} \kappa \mathrm{B} \alpha$ phosphorylation. Fig. 3b and Fig. 3c illustrate NF$\kappa \mathrm{B}$ expressions in the cytoplasm and nucleus, respectively. When I $\kappa \mathrm{B} \alpha$ is phosphorylated, NF- $\kappa \mathrm{B}$ is activated and translocated into the nucleus, acting as a transcription factor to increase inflammation- inducing cytokines. The LPS-induced NF- $\kappa$ B nuclear translocation is increased, resulting with nuclear $\mathrm{NF}-\kappa \mathrm{B}$ expression level. However, the nuclear NF- $\kappa \mathrm{B}$ levels were lowered by treatments of sandalwood oil $(0.3 \mu \mathrm{g} / \mathrm{ml}, 1.0 \mu \mathrm{g} / \mathrm{ml})$. Therefore, sandalwood oil inhibited I $\kappa \mathrm{B} \alpha$ phosphorylation and NF- $\kappa \mathrm{B}$ activation and its translocation into the nucleus.

Fig. 4 shows the results of immunofluorescence staining to visually confirm the translocation of NF$\kappa \mathrm{B}$ into the nucleus in LPS-induced inflammation of RAW 264.7 macrophage cells. Nuclear staining with DAPI and NF- $\kappa B$ staining with fluorescent antibody techniques were performed. NF- $\kappa B$ localized in the cytoplasm in the control group, while the LPS treated NF- $\kappa \mathrm{B}$ translocated from cytoplasm into the nucleus. However, the expression level of NF$\kappa \mathrm{B}$ was reduced by treatment of sandalwood oil ( $1 \mu \mathrm{g} / \mathrm{ml}$ ). The expression level of COX-2 was also increased in the LPS-treated group; however, the levels of COX-2 were significantly decreased in the groups treated with sandalwood oil (Fig. 5).

\section{DISCUSSION}

Inflammation is a defense mechanism that recovers damages resulting from physical and/or chemical stimuli or bacterial infection [25]. It is important to control inflammation because persistent inflammatory reactions promote mucosal injury, resulting in pain, swelling, redness, fever, and chronic diseases such as arthritis and cancer [26]. Recently, sandalwood oil has been reported to inhibit the production of TNF- $\alpha$, IL- $1 \beta$, and IL- 6 , which are inflammatory cytokines, in macrophages; however, the underlying mechanism of infection control was unclear [19]. In this study, we evaluated the effect of sandalwood oil on antioxidant and anti-inflammatory activities. ROS participates in signal transduction and gene regulation at physiological levels [13]. However, when the level of ROS is excessive beyond physiological levels, ROS denatures the surrounding proteins, lipids, and DNA, and activates signaling pathways leading to inflammation $[27,28]$. ROS is regulated by antioxidant enzymes such as superoxide dismutase, catalase, and glutathione peroxidase [29].

The antioxidant activity of sandalwood oil was measured in vitro (Fig. 1). Although DPPH and ABTS radicals are not biologically relevant, they help measure the ability of reducing antioxidants to yield hydrogen (Fig. 1a,b,c). In DPPH and ABTS radical scavenging activities, sandalwood oil had an antioxidant effects in a concentration dependent manner. Protective effects of sandalwood oil against 
(a)

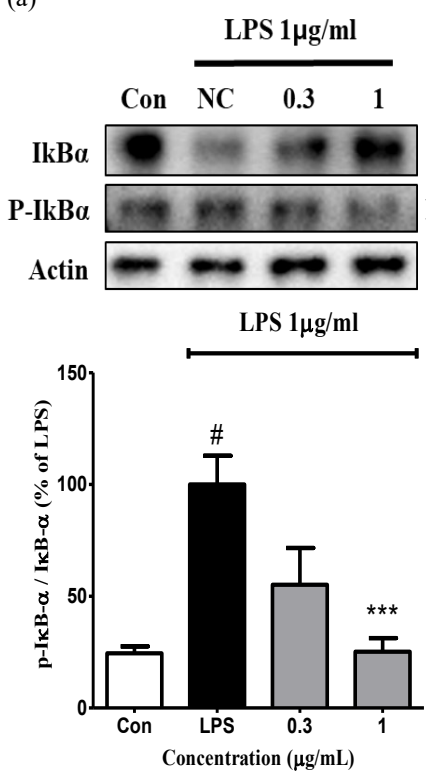

(b)

(c)

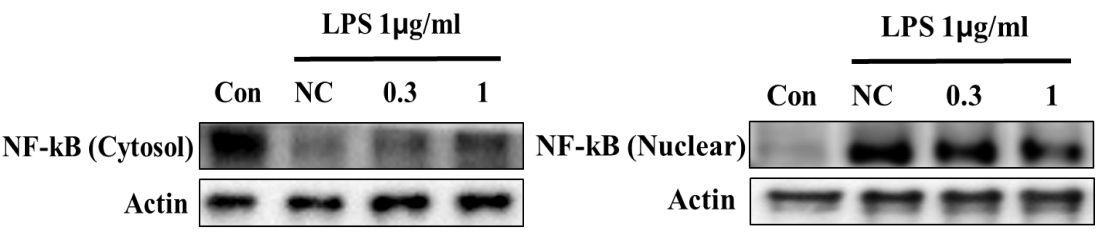

Fig. 3 Effects of different concentrations of sandalwood oil on protein expression levels of (a) I $\kappa \mathrm{B} \alpha$, (b) NF- $\kappa \mathrm{B}$ (Cytosol), and (c) NF- $\mathrm{BB}$ (Nuclear) in RAW 264.7 cells. RAW 264.7 cells were treated with LPS $(1 \mu \mathrm{g} / \mathrm{ml})$. ${ }^{\# \# \# ~} p<0.001$ were considered significant for control (not treated) vs. negative control; $* p<0.05$, $* * p<0.01$, and $* * * p<0.001$ were considered significant for negative control vs. sample.

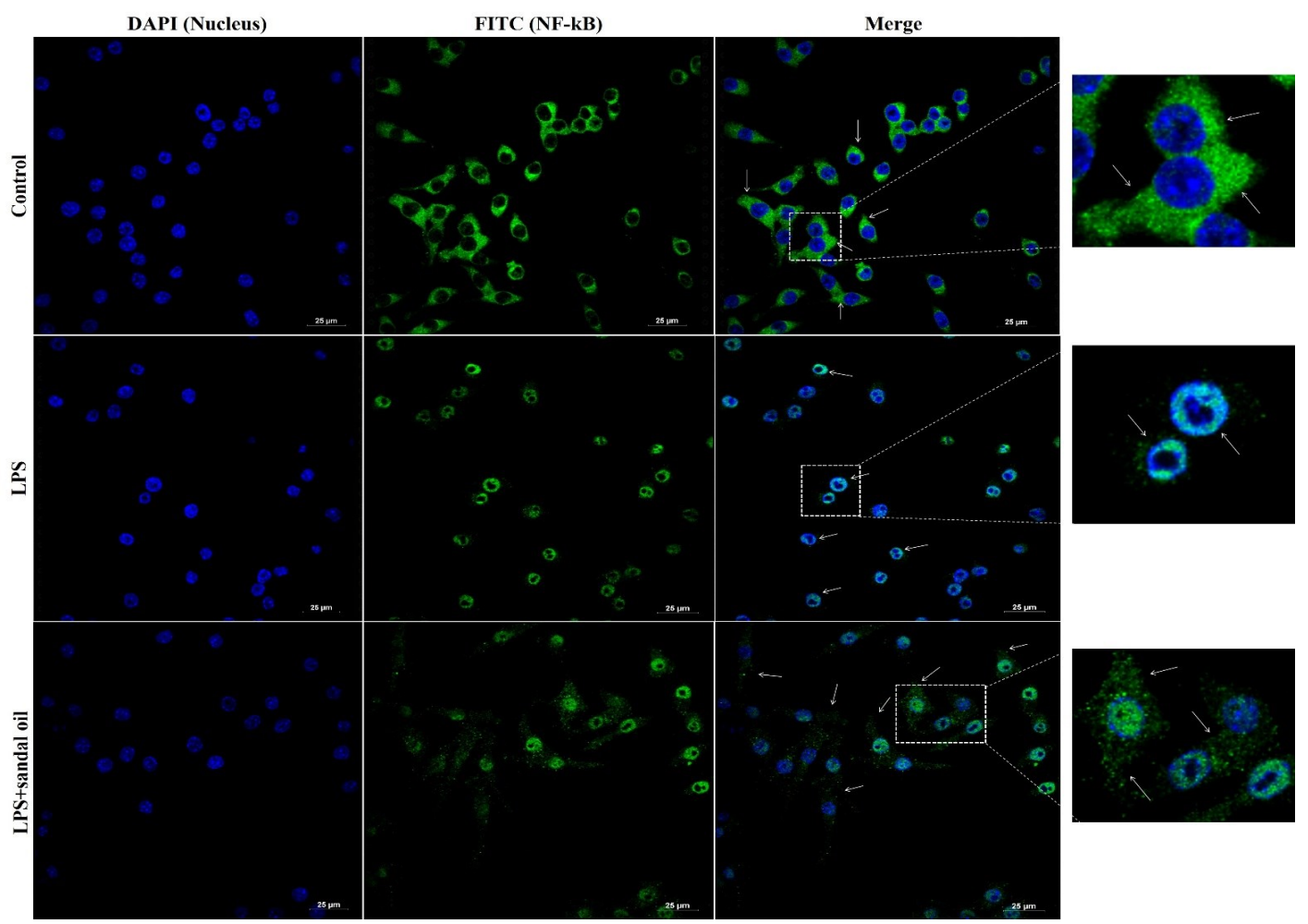

Fig. 4 Inhibition of NF- $\kappa B$ nuclear translocation in LPS-stimulated RAW 264.7 cells. For confocal microscopy (Olympus BX-40), the nucleus was stained (blue) with DAPI, whereas NF- $\kappa B$ was stained (green) with antibody against the phosphorylated form NF- $\mathrm{B}$ p65. 

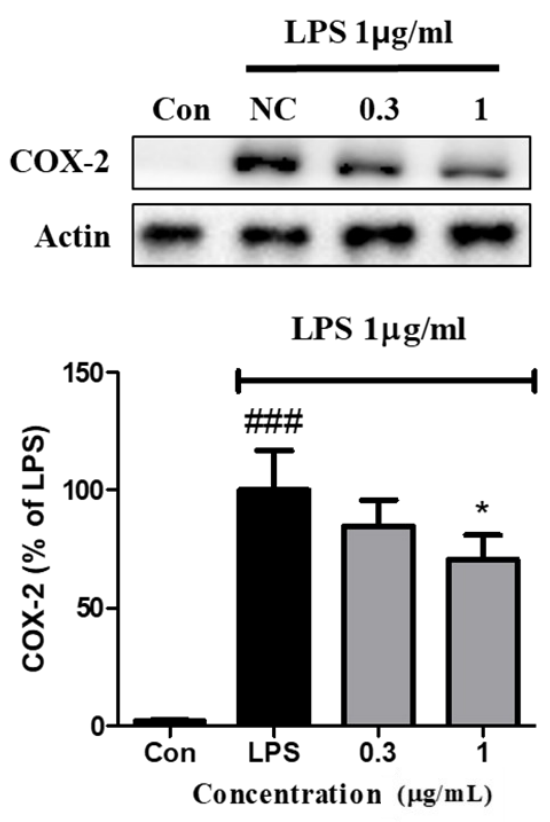

Fig. 5 Effects of different concentrations of sandalwood oil on protein expression levels of COX-2 in RAW 264.7 cells. RAW 264.7 cells were treated with LPS $(1 \mu \mathrm{g} / \mathrm{ml})$. \#\#\# $p<0.001$ were considered significant for control (not treated) vs. negative control; * $p<0.05$, were considered significant for negative control vs. sample.

DNA damages were evaluated by measuring the scavenging ability of hydroxyl free radical, the ROS that directly affects DNA [30]. Sandalwood oil was shown to protect DNA damages by acting against ROS (Fig. 1d).

The inhibitory effect of sandalwood oil on the production of $\mathrm{H}_{2} \mathrm{O}_{2}$-induced ROS in RAW cells was measured (Fig. 2). Treatment of sandalwood oil significantly inhibited intracellular ROS production by $\mathrm{H}_{2} \mathrm{O}_{2}$ treatment in RAW cells (Fig. 2b). ROS can stimulate inflammatory signaling pathways, such as MAPK and NF- $\mathrm{KB}$, by acting as secondary messengers in LPS-induced signaling [31]. These results suggest that inhibition of ROS by sandalwood oil treatment may attenuate ROS-induced inflammatory signaling. Three important MAP kinase cascades altering gene expressions, such as ERK, JNK, and p38 MAP kinase, are well-known. When the MAPK pathway is activated by LPS, MAP kinase cascades are activated and AP- 1 translocated into the nucleus and causing inflammation [32]. ERK, JNK, and p38 were quantified via western blotting after treatment with sandalwood oil in LPS-induced inflammation macrophages. However, there was no inhibitory effect of sandalwood oil on protein expression level of MAPK pathway (data not shown).

$\mathrm{NF}-\kappa \mathrm{B}$ is a transcription factor that plays an important role in the expression of many genes involving in immune and inflammatory responses. Regulation of NF- $\kappa \mathrm{B}$ is important because uncontrolled NF- $\kappa \mathrm{B}$ signaling results in the pathogenesis of many acute and chronic inflammatory diseases. NF- $\kappa \mathrm{B}$ is typically composed of a dimer of p50 and p65 (RelA) subunits and present in the cytoplasm, in an inactive state in association with the inhibitory protein I $\kappa \mathrm{B} \alpha$. For NF- $\kappa \mathrm{B}$ activation, I $\kappa \mathrm{B} \alpha$ bound to NF- $\kappa B$ is degraded by inflammatory signals induced by LPS [33]. In macrophages, when inflammatory signals are generated by LPS, IKK is activated in the cytoplasm and I $\mathrm{B} \alpha$ is phosphorylated to dissociate I $\kappa \mathrm{B} \alpha$ from NF- $\kappa \mathrm{B}$, thereby activating NF- $\kappa \mathrm{B}$. The activated NF- $\kappa \mathrm{B}$ is, then, translocated into the nucleus and induces inflammation by promoting the expression of various inflammatory factors including COX-2 [9]. I $\kappa \mathrm{B} \alpha$ functions as a transcription factor for NF- $\kappa \mathrm{B}$ and, then, regenerates and inactivates NF- $\kappa B$. When TNF- $\alpha$ induced inflammation in IкBaknockout cells, NF- $\mathrm{kB}$ reportedly remained at high levels in the nucleus for a long period [6].

Therefore, $I \kappa B \alpha$ is very important as a factor inhibiting NF- $\kappa \mathrm{B}$ activity. In this study, the expression of $I \kappa B \alpha$ in RAW264.7 cells was decreased by LPS treatment, while I $\kappa \mathrm{B} \alpha$ was increased; and the phosphorylated form in the sandalwood treated group was significantly reduced (Fig. 3a). The expression levels of cytoplasmic NF- $\kappa$ B (Fig. 3b) and nuclear NF- $\kappa B$ (Fig. 3c), were significantly increased and significantly decreased, respectively, in the sandalwood oil-treated groups. The translocation of NF$\kappa B$ was visually confirmed via immunofluorescence and DAPI stainings. Consequently, NF- $\kappa$ B fluorescence intensity was detected in the cytoplasms of macrophages rather than in the nuclei. After LPS treatment, nuclear NF- $\kappa B$ fluorescence intensity was increased (Fig. 4). However, by treatment with sandalwood oil, the intensity of nuclear NF- $\kappa B$ fluorescence decreased and the intensity of perinuclear NF- $\kappa$ B fluorescence increased (Fig. 4). These results suggested that sandalwood oil inhibited I $\mathrm{B} \alpha \alpha$ phosphorylation and translocation of NF$\kappa \mathrm{B}$. COX-2 is an important indicator of inflammatory response and expressed during inflammation. It promotes inflammation through the production of prostaglandin E2 and is, thus, very important in macrophages. COX-2 is regulated by NF- $\kappa \mathrm{B}$ [34]. In this study, COX-2 was significantly downregulated 
upon treatment with sandalwood oil in LPS-induced RAW264.7 cells (Fig. 5). Blocking the phosphorylation of I $\kappa \mathrm{B} \alpha$ inhibits NF- $\kappa \mathrm{B}$ nuclear translocation and represses the COX-2 $[35,36]$. In the present study, sandalwood oil could effectively inhibit COX2 expression by effectively reducing the activation of the NF- $\kappa B$ signaling pathway in RAW264.7 cells.

In conclusion, sandalwood oil showed antioxidant activity in vitro, suggesting that it may inhibit the promotion of the NF- $\kappa \mathrm{B}$-mediated inflammatory signaling pathway induced by ROS. Moreover, sandalwood oil inhibited NF- $\kappa$ B activation and translocation to the nucleus by blocking the phosphorylation of IKB $\alpha$ in RAW264.7 cells. Finally, sandalwood oil also suppressed the expression level of COX-2 by inhibiting NF- $\kappa \mathrm{B}$ activation. Therefore, the present results suggest that the anti-inflammatory effects of sandalwood oil can be induced through inhibition of the NF- $\kappa B$ signaling pathway. Sandalwood oil may be useful for controlling inflammatory pathways and for developing chemical prophylaxis by controlling NF- $\kappa \mathrm{B}$ inflammatory signaling.

Acknowledgements: This paper was supported by Konkuk University in 2018

\section{REFERENCES}

1. Ferrero-Miliani L, Nielsen $\mathrm{O}$, Andersen P, Girardin S (2007) Chronic inflammation: importance of NOD2 and NALP3 in interleukin-1 $\beta$ generation. Clin Exp Immunol 147, 227-235.

2. Iwalewa E, McGaw L, Naidoo V, Eloff J (2007) Inflammation: the foundation of diseases and disorders. A review of phytomedicines of South African origin used to treat pain and inflammatory conditions. Afr J Biotechnol 6, 2868-2885.

3. Jeong JB, Hong SC, Jeong HJ, Koo JS (2012) Anti-inflammatory effects of ethyl acetate fraction from Cnidium officinale Makino on LPS-stimulated RAW 264.7 and THP-1 cells. Korean $J$ Plant Res 25, 299-307.

4. Kaminska B (2005) MAPK signalling pathways as molecular targets for anti-inflammatory therapy from molecular mechanisms to therapeutic benefits. Biochim Biophys Acta 1754, 253-262.

5. Son Y, Kim S, Chung HT, Pae HO (2013) Reactive oxygen species in the activation of MAP kinases. Methods Enzymol 528, 27-48.

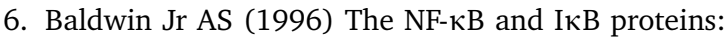
new discoveries and insights. Annu Rev Immunol 14, 649-681.

7. Chen YC, Yang LL, Lee TJ (2000) Oroxylin A inhibition of lipopolysaccharide-induced iNOS and COX-2 gene expression via suppression of nuclear factor- $\kappa \mathrm{B}$ activation. Biochem Pharmacol 59, 1445-1457.
8. Yoon YI, Hwang JS, Kim MA, Ahn MY, Lee YB, Han MS, Goo TW, Yun EY (2015) Inhibition of inflammation by Popillia flavosellata ethanol extract in LPS-induced RAW264.7 macrophages. J Life Sci 25, 993-999.

9. Tak PP, Firestein GS (2001) NF- $\kappa$ B: a key role in inflammatory diseases. $J$ Clin Invest 107, 7-11.

10. Kim SJ, Kim MC, Lee BJ, Park DH, Hong SH, Um JY (2010) Anti-inflammatory activity of chrysophanol through the suppression of NF- $\kappa \mathrm{B} /$ caspase- 1 activation in vitro and in vivo. Molecules 15, 6436-6451.

11. Ji JD, Lee YH, Song GG (2004) Prostaglandin E2 (PGE2): Roles in immune responses and inflammation. J Korean Rheum Assoc 11, 307-316.

12. Genova ML, Pich MM, Bernacchia A, Bianchi C, Biondi A, Bovina C, Falasca AI, Formiggini G, et al (2004) The mitochondrial production of reactive oxygen species in relation to aging and pathology. Ann NY Acad Sci 1011, 86-100.

13. Hensley K, Robinson KA, Gabbita SP, Salsman S, Floyd RA (2000) Reactive oxygen species, cell signaling, and cell injury. Free Radic Biol Med 28, 1456-1462.

14. Gloire G, Legrand-Poels S, Piette J (2006) NF- $\kappa B$ activation by reactive oxygen species: fifteen years later. Biochem Pharmacol 72, 1493-1505.

15. Morgan MJ, Liu Zg (2011) Crosstalk of reactive oxygen species and NF- $\mathrm{KB}$ signaling. Cell Res 21, 103-115.

16. Nautiyal $\mathrm{OH}$ (2014) Process optimization of sandalwood (Santalum album) oil extraction by subcritical carbon dioxide and conventional techniques. Indian J Chem Technol 21, 290-197.

17. Sharma M, Levenson C, Bell R, Anderson S, Hudson J, Collins C, Cox M (2014) Suppression of lipopolysaccharide-stimulated cytokine/chemokine production in skin cells by sandalwood oils and purified $\alpha$-santalol and $\beta$-santalol. Phytother Res 28, 925-932.

18. Celedon JM, Chiang A, Yuen M, Diaz-Chavez ML, Madilao LL, Finnegan PM, Barbour EL, Bohlmann J (2016) Heartwood-specific transcriptome and metabolite signatures of tropical sandalwood (Santalum album) reveal the final step of (Z)-santalol fragrance biosynthesis. Plant $J$ 86, 289-299.

19. Park JS, Jung SH (2013) Effects of sandalwood essential oil on the iNOS expression and proinflammatory cytokine production. Yakhak Hoeji 57, 70-75.

20. Jeong CH, Choi GN, Kim JH, Kwak JH, Heo HJ, Shim KH, Cho BR, Bae YI, et al (2009) In vitro antioxidative activities and phenolic composition of hot water extract from different parts of Cudrania tricuspidata. J Food Sci Nutr 14, 283-289.

21. Hu W, Shen W, Wang MH (2009) Free radical scavenging activity and protective ability of methanolic extract from Duchesnea indica against protein oxidation and DNA damage. J Food Sci Nutr 14, 277-282. 
22. Tian B, Hua Y (2005) Concentration-dependence of prooxidant and antioxidant effects of aloin and aloeemodin on DNA. Food Chem 91, 413-418.

23. Tsai SH, Lin-Shiau SY, Lin JK (1999) Suppression of nitric oxide synthase and the down-regulation of the activation of NFKB in macrophages by resveratrol. $\mathrm{Br}$ $J$ Pharmacol 126, 673-680.

24. Giuliani C, Napolitano G, Bucci I, Montani V, Monaco $F$ (2001) Nf- $\kappa B$ transcription factor: role in the pathogenesis of inflammatory, autoimmune, and neoplastic diseases and therapy implications. Clin Ter 152, 249-253.

25. Medzhitov R (2008) Origin and physiological roles of inflammation. Nature 454, 428-435.

26. Ljung $T$, Lundberg S, Varsanyi $M$, Johansson C, Schmidt PT, Herulf M, Lundberg JO, HellstrÖm PM (2006) Rectal nitric oxide as biomarker in the treatment of inflammatory bowel disease: responders versus nonresponders. World $J$ Gastroenterol 12, 3386-3392.

27. Masaki H (2010) Role of antioxidants in the skin: anti-aging effects. J Dermatol Sci 58, 85-90.

28. Blaser H, Dostert C, Mak TW, Brenner D (2016) TNF and ROS crosstalk in inflammation. Trends Cell Biol 26, 249-261.

29. Birben E, Sahiner UM, Sackesen C, Erzurum S, Kalayci O (2012) Oxidative stress and antioxidant defense. World Allergy Organ J 5, 9-19.

30. Samad NB, Debnath T, Ye M, Hasnat MA, Lim BO (2014) In vitro antioxidant and anti-inflammatory activities of Korean blueberry (Vaccinium corymbosum L.) extracts. Asian Pac J Trop Biomed 4, 807-815.

31. Tan HY, Wang N, Li S, Hong M, Wang X, Feng Y (2016) The reactive oxygen species in macrophage polarization: reflecting its dual role in progression and treatment of human diseases. Oxidative Med Cell Longev 2016, ID 2795090.

32. Cargnello M, Roux PP (2011) Activation and function of the MAPKs and their substrates, the MAPKactivated protein kinases. Microbiol Mol Biol Rev 75, 50-83.

33. Liu Z, Wang Y, Ning Q, Gong C, Zhang Y, Zhang L, Bu $X$, Jing $G$ (2015) The role of spleen in the treatment of experimental lipopolysaccharide-induced sepsis with dexmedetomidine. SpringerPlus 4, ID 800.

34. Seo K, Yang JH, Kim SC, Ku SK, Ki SH, Shin SM (2014) The antioxidant effects of isorhamnetin contribute to inhibit COX-2 expression in response to inflammation: a potential role of HO-1. Inflammation 37, 712-722.

35. Kim CS, Kawada T, Kim BS, Han IS, Choe SY, Kurata T, Yu R (2003) Capsaicin exhibits anti-inflammatory property by inhibiting I $\mathrm{KB}$-a degradation in LPSstimulated peritoneal macrophages. Cell Signal 15, 299-306.

36. Bayazid AB, Park SH, Kim JG, Lim BO (2020) Green chicory leaf extract exerts anti-inflammatory effects through suppressing LPS-induced MAPK/NF- $\kappa \mathrm{B}$ activation and hepatoprotective activity in vitro. Food Agric Immunol 31, 513-532. 